\title{
Teacher emotions in the classroom: associations with students' engagement, classroom discipline and the interpersonal teacher-student relationship
}

\author{
Gerda Hagenauer • Tina Hascher • Simone E. Volet
}

Received: 29 September 2014 / Revised: 23 February 2015 / Accepted: 2 March 2015 /

Published online: 15 March 2015

(C) Instituto Superior de Psicologia Aplicada, Lisboa, Portugal and Springer Science+Business Media Dordrecht 2015

\begin{abstract}
The present study explores teacher emotions, in particular how they are predicted by students' behaviour and the interpersonal aspect of the teacher-student relationship (TSR). One hundred thirty-two secondary teachers participated in a quantitative study relying on self-report questionnaire data. Based on the model of teacher emotions by Frenzel (2014), teachers rated their experienced joy, anger and anxiety during classroom instruction (dependent variable). Students' motivational behaviour (= engagement), socio-emotional behaviour (= discipline in class) and relational behaviour (= closeness; interpersonal TSR) were assessed as the independent variables. Teachers' self-efficacy beliefs served as a control variable. Hierarchical regression analysis revealed that the interpersonal relationship formed between teachers and students was the strongest predictor for teachers' joy (positive relation) and anxiety (negative relation), whereas lack of discipline in class best predicted teachers' anger experiences. Students' engagement also proved a significant predictor of teacher emotions. The results suggest that interpersonal TSR plays a particularly important role in teachers' emotional experiences in class.
\end{abstract}

Keywords Teacher emotion · Teacher-student relationship · Classroom management · Teacher wellbeing

\section{Introduction}

Emotions in education have been recognized as significant antecedents of students' learning and achievement (Glaeser-Zikuda et al. 2013; Hascher 2010; Järvelä 2011; Newberry et al.

G. Hagenauer $(\varangle) \cdot$ T. Hascher Institute of Educational Science, Department of Research on School, Learning and Instruction, University of Bern, Fabrikstrasse 8, 3012 Bern, Switzerland e-mail: gerda.hagenauer@edu.unibe.ch

T. Hascher

e-mail: tina.hascher@edu.unibe.ch

S. E. Volet

School of Education, Murdoch University, South Street 90, Murdoch, Perth, Australia e-mail: s.volet@murdoch.edu.au 
2013; Pekrun and Linnenbrink-Garcia 2014; Schutz and Pekrun 2007). Although the topic is attracting increasing interest in educational research (e.g. Schutz and Zembylas 2011), the empirical evidence on teacher emotions is not extensive (Frenzel 2014). Studies on teacher emotions suggest that teaching is an emotional endeavour (Hargreaves 1998, 2000), and that teachers' emotions correlate with their wellbeing and the quality of their teaching (Brackett et al. 2013; Day and Gu 2011; Frenzel 2014; Frenzel et al. 2011). The same has been shown in the higher education context: Trigwell (2012) and Postareff and Lindblom-Ylänne (2011) found a link between teachers' positive emotions and student-centred approaches to teaching. Thus, the identification of factors influencing teacher emotions at school can make a significant contribution towards determining how to support teachers' wellbeing and teaching quality.

The present study explores the antecedents of teacher emotions, focusing on student behaviour in the classroom and the interpersonal relationship that is formed between teachers and students. Previous studies have shown that students' behaviour in the context of teacher-student interactions can be crucial to teacher emotions (e.g. Frenzel et al. 2011), yet the impact of the interpersonal teacher-student relationship (TSR) and its significance for teachers and their emotions has to date been largely neglected in research (Klassen et al. 2012; Spilt et al. 2011). Consequently, the present study contributes to the research strands on teacher emotions and TSR in the classroom by simultaneously investigating the predictive power of students' behaviour and the quality of TSR on teacher emotions.

\section{A conceptual model of teacher emotions}

The conceptual framework for the present study is underpinned by Frenzel's model of teacher emotions (2014), which defines emotions from an appraisal theoretical perspective (Ellsworth and Scherer 2003; Scherer 2004). Frenzel's appraisal model implies that the emotional response of an actor depends on his or her evaluation of the situation. Classroom goals and their attainment or non-attainment appear to be particularly significant in the appraisal process. Frenzel (2014) and Frenzel et al. (2011) argued that teachers follow different teaching goals, observe the behaviour of students related to their goals and then appraise this behaviour (e.g. in terms of goal attainment), which contributes to their respective emotions. For example, if a teacher judges a situation as goal congruent (i.e. students are motivationally engaged; see also the research on teacher motivation by Mansfield and Beltman 2014) and manageable (secondary appraisal; Lazarus 1999), it is likely that positive emotions would be experienced (e.g. satisfaction or joy; Schutz et al. 2011).

Control-value theory (Pekrun 2006), or transactional stress theory (Lazarus 1999), posits that, in terms of the perception of manageability of a situation, the self-efficacy beliefs of teachers play an important role. Self-efficacy beliefs "refer to individuals' beliefs about their capabilities to successfully carry out a particular course of action" (Klassen et al. 2009, p. 67). Previous studies have shown that teachers' self-efficacy is related to affective variables, for example, teachers' emotional exhaustion (Skaalvik and Skaalvik 2010) or job satisfaction (Klassen and Chiu 2010; Vieluf et al. 2013).

According to the model of Frenzel (2014), four main teaching goals and the respective student behaviour are identified: (1) achievement behaviour, (2) motivational behaviour, (3) social-emotional behaviour and (4) relational behaviour. The model was introduced by Frenzel and colleagues in 2011 and comprised the first three modes of goal-relevant student behaviour. It was extended by Frenzel in 2014 by the addition of a fourth dimension of the relational aspect, which incorporates recent research 
findings that have addressed more explicitly the social dimension of teacher motivation (e.g. Butler 2012).

The concept of interpersonal TSR introduced in this study is similar to what has been defined by Frenzel (2014) as relational behaviour. However, in the present study, the term "interpersonal TSR" extends Frenzel's relational behaviour in order to capture the way in which interpersonal relationships, i.e. the affective bond built between students and teachers, go beyond observable student behaviour. Whilst observable relational behaviour of students (e.g. friendly smiles to a teacher) contributes to the formation of TSR, interpersonal TSR is a product of the interaction of teacher and student behaviour over time (Spilt et al. 2011).

Teacher emotions in the classroom and student classroom behaviour

Teachers experience a range of emotions during their work (Frenzel 2014; Keller et al. 2014), which are triggered by multiple factors and their interplay (Schutz 2014). Teacher emotions typically unfold in interaction with their environment (Day and Gu 2014). Teachers interact with different people in their work (e.g. colleagues, parents), but interactions with their students seem to be the most powerful in terms of evoking positive or negative emotions, as (mostly qualitative) empirical studies have shown (e.g. Sutton and Wheatley 2003). For example, teachers in the study of O'Connor (2006) described their "big moments" (p. 125) in terms of emotionality in teaching resulting from interaction sequences with students. This finding was confirmed in several other studies (Demetriou et al. 2009; Galant 2013; Hargreaves 1998, 2000; Oplatka 2007; Sutton 2007; Williams-Johnson et al. 2008; Zembylas 2002).

Research has shown that primary and secondary teachers' emotions are strongly connected to positive interactions with their students (e.g. a breakthrough of a learner, showing appreciation of the teachers' work), evoking responses such as joy and satisfaction (Hargreaves 2000). Conversely, in terms of negative emotions, a recent study by Chang (2013) showed that negative emotions of teachers (e.g. anger and frustration) were frequently related to students' misbehaviour or lack of classroom discipline, which increased the risk for burnout over time (Tsouloupas et al. 2010). Classroom discipline problems have also been found to be one of the main predictors of teacher stress (Abel and Sewell 1999; McCarthy et al. 2015) and also impede on teacher enthusiasm (Kunter et al. 2011). Frenzel et al. (2011) found a positive correlation between discipline in the classroom and teacher enjoyment, whilst the correlation was negative for anger (Sutton 2007) and anxiety. The same correlational pattern occurred for student motivation, whilst there was no significant association between student performance and teacher emotions (Frenzel et al. 2011). This corresponds with findings of previous studies in motivation and the TSR, indicating that student engagement was more significant for teachers' positive relationship with students than students' achievement level (e.g. Juvonen 2006; Skinner and Belmont 1993; Tal and Babad 1990).

Teacher emotions in the classroom and the quality of the interpersonal teacher-student relationship

Based on the assumption that positive and secure relationships are of fundamental importance for human functioning, since it reflects the "basic need to belong" (e.g. Baumeister and Leary 1995; Cassidy and Shaver 2008; Deci and Ryan 2002), the quality of TSR is expected to contribute to teacher emotions and satisfaction in the 
job. Whilst the empirical evidence on the significance of TSR for students' learning and achievement is extensive (for reviews, see Cornelius-White 2007; Roorda et al. 2011), only a few studies have pointed to the relevance of TSR for teacher emotions in their work, and these studies rely mostly on qualitative (interview) data (e.g. den Brok et al. 2013; Hargreaves 2000).

Given the significantly differing roles of students and teachers, the concepts emerging from TSR research into students' perspectives cannot be simply transferred to teachers. Similarly, Urdan (2014) argued that conceptualisations, and derived methodologies for the study of student motivation could not simply be transferred to the study of teacher motivation (e.g. achievement goal theory). Thus, the concept of TSR from a teachers' perspective requires clarification.

TSR is a multidimensional construct. It is formed on different dimensions, including interpersonal and professional (Hagenauer and Volet 2014). Hagenauer and Volet referred to these two dimensions of TSR as "affective" and "support." The support dimension represents the professional relationship (e.g. students and teachers mutually contribute to a supportive learning and teaching environment), and the affective dimension incorporates the interpersonal or affective connection that is formed between teachers and students, reflecting the degree of affiliation (e.g. warm, caring, trusting relationships; Newberry and Davis 2008). In the present study, the focus is placed on the latter and its significance for teacher emotions. Similarly to that of den Brok et al. (2013), the term "interpersonal TSR" is used in this study to distinguish it clearly from the professional TSR. In attachment theory approaches, the interpersonal dimension of TSR is frequently coined as "closeness" (e.g. Pianta 2001; Bergin and Bergin 2009). As Riley (2009, 2011) observed, the interpersonal TSR can be considered as an "attachment dyad," acknowledging that teachers are not only caregivers but also care-seekers in the TSR. The research of Hargreaves (2000) showed that the interpersonal TSR frequently evoked emotions in teachers, and that the primary school environment held higher likelihood of positive emotions as primary education structurally allows for stronger interpersonal emotional bonds. These stronger bonds in primary education were also revealed in the Australian study of Riley (2009) that applied an attachment theory approach (see also Lynch and Cicchetti 1997 for a study of students' perspective). One reason this study focused on secondary teachers was to explore for effects of possibly weaker bonds between students and teachers, on teacher emotions.

\section{The present study}

Given the paucity of research on the antecedents of teacher emotions, as well as on the association between TSR and teacher-related outcome variables (Klassen et al. 2012; Spilt et al. 2011), the current study aimed to link these two research strands by examining the extent to which perceived student behaviour and the interpersonal TSR predict teacher emotions during instruction. Based on the model of teacher emotions by Frenzel (2014) as well as on the more general notion that the quality of relationships is fundamental for subjective wellbeing (e.g. Baumeister and Leary 1995), we expected that goal-conducive student behaviour as well as a positive interpersonal TSR would be related positively to positive and negatively to negative teacher emotions.

More concretely, as displayed in Fig. 1, we hypothesized that students' engagement in the classroom (= motivational behaviour) and a positive interpersonal TSR (= 


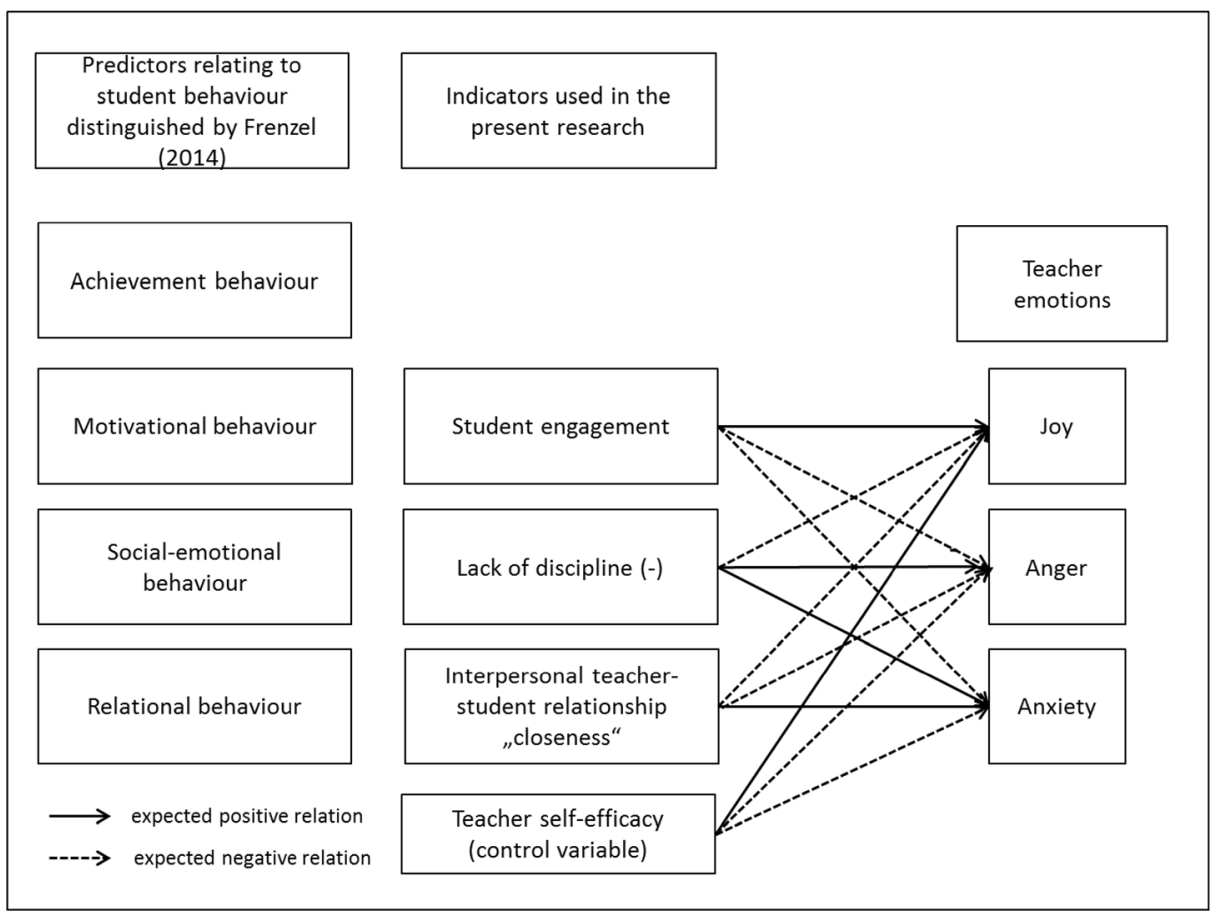

Fig. 1 Conceptual model tested in the present study

relational behaviour) would be positively associated with joy, and negatively with anxiety and anger, whilst the reverse association was expected for the negative indicator "lack of discipline in class" (= social-emotional behaviour). Self-efficacy beliefs of teachers were treated as a control variable, as emotions are influenced by the control cognitions of the teachers (see control-value theory, Pekrun 2006), in order to assess the adjusted association between student behaviour variables and teacher emotions.

\section{Method}

\section{Participants}

One hundred thirty-two teachers participated in the study (65.6\% female, $n=86$; $34.4 \%$ male, $n=45$ ). They all taught in high-track secondary schools in Austria. Stemming from 11 different schools, a range between 2 and 31 teachers from each school participated voluntarily in this study. The mean age was 47.12 years $(\min =25$, $\max =62$ years). The majority of the teachers were experienced teachers with a mean of 20.56 years of experience in the job ( $\min =0.5$ years to $\max =43$ years); $69 \%$ of the participating teachers were full-time employed. On average, the classroom size in high-track schools was about 25 students per class. 
Measures

Based on the findings of Kunter et al. (2011) that teacher enthusiasm can vary significantly between classrooms, teachers in the present study were asked to focus on one classroom when answering the items concerning the classroom conditions. This was deemed necessary in order to capture the possibility of high variation of the quality of teacher-student interactions and, thus, teacher emotions between classrooms (student populations). Accordingly, teachers were invited to nominate a classroom that was of high relevance to them ("goal relevance" of the situation as a key appraisal evoking positive or negative emotions; Frenzel 2014; Lazarus 1999). "Relevance" was operationalized in terms of the frequency of interactions with and responsibility for this particular group of students. The order of how the choice should be made was suggested to the teachers ((1) class teacher, (2) major subject area, (3) minor subject area). This led to the following classroom selection when responding to the items: $40 \%$ of the teachers focused on the classroom in which they were the class teacher (also called "form teacher" in the UK or "homeroom teacher" in the USA); another $27 \%$ referred to a class of students where they taught one of the major subject areas (Language of Instruction, Mathematics or First Foreign Language); and $32 \%$ referred to classrooms in which they taught a minor subject area (e.g. Biology, Arts), thus where they typically taught fewer lessons per week per class. Furthermore and as requested, all teachers focused on a class of students from lower secondary education (grades 5 to 8 ). Finally, $14.5 \%$ of the teachers focused in their responses on teaching experiences in grade 5, 23.7\% in grade $6,29.8 \%$ in grade 7 and $32.1 \%$ in grade 8 .

Self-efficacy beliefs were measured on a group-unspecific level. The scales used in this study are fully described in the next paragraph. All responses were from $1=$ strongly disagree to $4=$ strongly agree.

\section{Teacher emotions}

Frenzel et al.'s (2010) questionnaire was used to measure teachers' joy, anger and anxiety during instruction. The joy scale contained four items (e.g. "I enjoy teaching these students"; $\alpha=0.93$ ); anger, three items (e.g. "I often feel annoyed while teaching these students"; $\alpha=0.85$ ), and anxiety, four items (e.g. "I feel tense and nervous while teaching these students"; $\alpha=0.81$ ).

\section{Teachers' self-efficacy}

We attempted to measure self-efficacy as a multidimensional construct, as suggested by several prior studies (e.g. TSES: Tschannen-Moran and Woolfolk Hoy 2001 or NTSES: Skaalvik and Skaalvik 2007). The instrument used for the present study captured three dimensions of teachers' self-efficacy: self-efficacy in teaching content, self-efficacy in classroom management and selfefficacy in relationship building. The first two dimensions were measured using scales that combined items from the German scale on teachers' self-efficacy developed by Jerusalem et al. (2009) as well as items of the internationally well-known scale of Woolfolk and Hoy (1990). The scale measuring self-efficacy in teaching content contained four items $(\alpha=0.72$; e.g. "I am confident that my teaching style is effective and that students learn a lot in my class") and the scale measuring self-efficacy in classroom management, three items $(\alpha=0.86$; e.g., "If a student becomes disruptive and noisy in my class, I feel assured that I know some techniques to redirect him/her quickly"). In contrast, the scale to measure self-efficacy in relationship building was newly developed for the present study, as this dimension has not been treated as independent in prior research. This original scale contained five items $(\alpha=0.84$; e.g. "It is easy for me to connect 
well with my students"; "Even if my students behave reserved, I am able to shape positive relationships with them"). Exploratory factor analysis (EFA) with principal component analysis and varimax rotation with Kaiser normalization confirmed the proposed three-factor structure (relationship building, teaching, classroom management) accounting for $65 \%$ of explained variance, in total. Items' factor loadings and commonalities were satisfactory.

\section{Teachers' perception of student behaviour}

As aforementioned, student behaviour was differentiated regarding its motivational, socialemotional and relational aspect. A "closeness" scale, adapted from Ang (2005) and Pianta (2001), measured students' relational behaviour reflecting the interpersonal TSR. Recently, Klassen et al. (2013) have developed a similar scale called "social engagement," a sub-scale of the "Engaged Teacher Scale." However, whilst the scale of Klassen et al. focuses on teacher behaviour that contributes to establish a positive interpersonal TSR (= energy that is invested in establishing relationships; e.g. "In class, I am empathic towards my students"), the scale in our study measures the outcome, namely the quality of the perceived TSR.

Students' motivational behaviour was assessed by the scale "students' engagement in the classroom" (SARAC; adapted from Wellborn and Connell n.d.) and students' socio-emotional behaviour by the scale "lack of discipline in class" (adapted from Baumert et al. 2008).

Altogether, there were 15 items: five measuring the latent construct of closeness (e.g. "I don't feel connected to the students in this class"; reverse coded; "I like the students in this class"), six addressing students' engagement in the classroom (e.g. "In this class, the students work as hard as they can") and four assessing lack of discipline in class (e.g. "In this class, students chat a lot").

EFA with principal component analysis and varimax rotation with Kaiser normalization were applied to test for the factor structure. The proposed three-factor solution could be confirmed accounting for $70 \%$ of explained variance, in total. All items' factor loadings were above 0.68 and loaded distinctly on one single factor (see Table 1).

Table 1 Factor loadings resulting from EFA

\begin{tabular}{llll}
\hline & $\begin{array}{l}\text { Factor 1: student } \\
\text { engagement }\end{array}$ & $\begin{array}{l}\text { Factor 2: } \\
\text { closeness }\end{array}$ & $\begin{array}{l}\text { Factor 3: lack } \\
\text { of discipline }\end{array}$ \\
\hline Eng1 & 0.83 & 0.31 & -0.05 \\
Eng2 & 0.80 & 0.24 & -0.14. \\
Eng3 & 0.77 & 0.14 & -0.23 \\
Eng4 & 0.71 & 0.29 & -0.32 \\
Eng5 & 0.69 & 0.30 & -0.23 \\
Eng6 & 0.69 & 0.25 & -0.29 \\
Clos1 & 0.16 & 0.84 & -0.11 \\
Clos2 & 0.20 & 0.72 & -0.33 \\
Clos3 & 0.39 & 0.71 & -0.26 \\
Clos4 & 0.37 & 0.70 & -0.21 \\
Clos5 & 0.41 & 0.68 & -0.23 \\
L_dis1 & -0.23 & -0.23 & 0.81 \\
L_dis2 & -0.12 & -0.24 & 0.80 \\
L_dis3 & -0.29 & -0.27 & 0.80 \\
L_dis4 & -0.22 & -0.11 & 0.78 \\
\hline
\end{tabular}


Table 2 Model comparison resulting from $\mathrm{CFA}$

\begin{tabular}{llll}
\hline & 3-factor model & 1-factor model & 2-factor model \\
\hline$\chi^{2}(d f)$ & $134.528(87)$ & $384.33(90)$ & $315.36(89)$ \\
$\chi^{2} / d f$ & 1.55 & 4.27 & 3.54 \\
CFI & 0.96 & 0.76 & 0.81 \\
TLI & 0.95 & 0.72 & 0.78 \\
RMSEA & 0.06 & 0.16 & 0.14 \\
SRMR & 0.05 & 0.09 & 0.09 \\
\hline
\end{tabular}

In order to empirically test the factor structure of the model of Frenzel (2014), a confirmatory factor analysis (CFA) was conducted with the software Mplus (Muthén and Muthén 1998-2012). A three-factor model was compared to a one-factor and a two-factor model. The one-factor model tested the one-dimensional way of assessing student behaviour (= one general factor), whilst the two-factor model explored whether it would be sensible to combine the indicators of student engagement and lack of discipline into one single dimension, whilst keeping closeness as a distinct indicator. The three-factor model was the conceptually derived model. As shown in Table 2, the three-factor solution presented the best fit, which supported the theoretically based model. This model is displayed in Fig. 1. Reliability analysis also revealed satisfactory internal consistencies for the derived three factors (student engagement, $\alpha=0.91$; lack of discipline, $\alpha=0.88$; closeness, $\alpha=0.87$ ). Thus, the three-factor model of TSR was used for data analysis (Fig. 2).

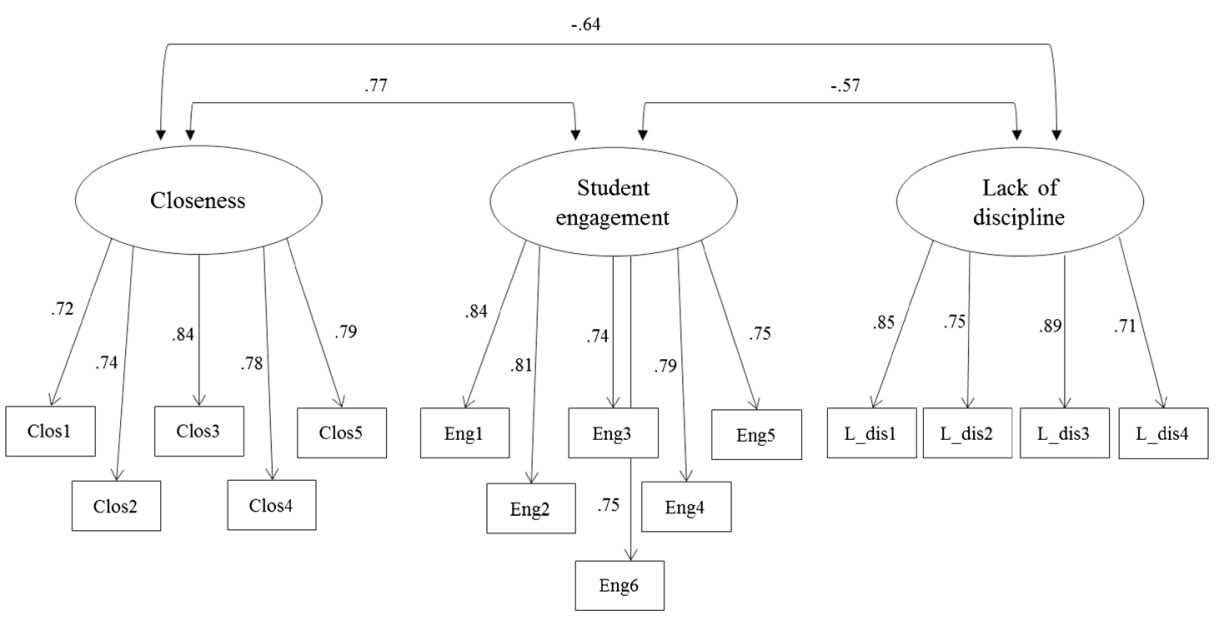

Fig. 2 Three-factor model—results of CFA 


\section{Results}

Descriptive statistics and intercorrelations

Descriptive statistics for all variables are presented in Table 3. In terms of emotions, the mean was highest for joy, followed by anger and anxiety. There were strong intercorrelations between teacher emotions and factors of student behaviour in the classroom, whilst the correlations were lower with self-efficacy beliefs. As expected, joy correlated negatively with anger and anxiety, whilst it correlated positively with student engagement and closeness and negatively with lack of discipline in the classroom. An independent $t$ test showed no significant difference between male and female teachers in their emotional experiences (joy: $t(129)=-0.42, p=0.67$; anxiety: $t(129)=0.34, p=0.73$; anger: $t(129)=-0.29, p=0.76)$. Correlations between teachers' years of teaching experience and emotions also resulted in non-significant results $(p>0.05)$.

We also tested for mean differences between the three groups (homeroom teacher, teacher of a major subject area and teacher of a minor subject area) of teachers' perspective, in terms of teacher emotions and student behaviour that were assessed as classroom specific. Significant differences were found for experience of joy, closeness and student engagement. Homeroom teachers (group 1) experienced significantly more joy $\left(F 2,131=6.70, p=0.002 ; \eta^{2}=0.09 ; M_{1}=3.46, \mathrm{SD}_{1}=0.53 ; M_{3}=2.96, \mathrm{SD}_{3}=0.83\right)$, as well as a greater extent of closeness to their students $(F 2,131=7.91, p=0.001$; $\left.\eta^{2}=0.11 ; M_{1}=3.80, \mathrm{SD}_{1}=0.28 ; M_{3}=3.44, \mathrm{SD}_{3}=0.60\right)$ and also reported more student engagement $\left(F 2,131=5.96, p=0.003 ; \eta^{2}=0.08 ; M_{1}=3.18, \quad \mathrm{SD}_{1}=0.57 ; M_{3}=2.78\right.$,

Table 3 Intercorrelations, means and standard deviations

\begin{tabular}{|c|c|c|c|c|c|c|c|c|c|}
\hline & Joy & Anxiety & Anger & SE_RB & SE_ET & SE_CM & ENG & L_DIS & CLOS \\
\hline Joy & - & $-0.65 * * *$ & $-0.71 * * *$ & $0.32 * * *$ & $0.43 * * *$ & $0.33 * * *$ & $0.72 * * *$ & $-0.61 * * *$ & $0.80 * * *$ \\
\hline Anxiety & & - & $0.67 * * *$ & $-0.34 * * *$ & $-0.28 * *$ & $-0.40 * * *$ & $-0.54 * * *$ & $0.58 * * *$ & $-0.64 * * *$ \\
\hline Anger & & & - & $-0.20 *$ & $-0.19 *$ & $-0.23 * *$ & $-0.61 * * *$ & $0.74 * * *$ & $-0.65 * * *$ \\
\hline SE_RB & & & & - & $0.56 * * *$ & $0.58 * * *$ & $0.22 *$ & -0.11 & $0.28 * * *$ \\
\hline SE_ET & & & & & - & $0.56 * * *$ & $0.27 * *$ & $-0.19 *$ & $0.21 *$ \\
\hline SE_CM & & & & & & - & $0.28 * *$ & $-0.31 * * *$ & $0.28 * *$ \\
\hline ENG & & & & & & & - & $-0.51 * * *$ & $0.69 * * *$ \\
\hline L_DIS & & & & & & & & - & $-0.56^{* * *}$ \\
\hline CLOS & & & & & & & & & - \\
\hline$M$ & 3.21 & 1.44 & 1.95 & 3.27 & 3.13 & 3.12 & 2.94 & 2.42 & 3.59 \\
\hline SD & 0.71 & 0.62 & 0.81 & 0.49 & 0.42 & 0.62 & 0.66 & 0.85 & 0.52 \\
\hline
\end{tabular}

Scale $\min =1, \max =4$

$S E \_R B$ self-efficacy in relationship building, $S E \_E T$ self-efficacy in effective teaching of content, $S E \_C M$ selfefficacy in classroom management, $E N G$ student engagement, $L \_D I S$ lack of discipline in class, CLOS closeness $* * * p<0.001 ; * * p<0.01 ; * p<0.05 ;{ }^{+} p<0.10$ 
$\mathrm{SD}_{3}=0.64$ ) in comparison to teachers who taught minor subject areas (group 3). On a descriptive level, homeroom teachers also scored lowest on anger, anxiety and lack of discipline in class; however, the three groups were not significantly different in regard to these experiences $(p>0.05)$.

\section{Predicting teacher emotions}

In order to test the assumption that student motivational, socio-emotional and relational (TSR) behaviour predicts teacher emotions, hierarchical regression analyses were applied for the criterion variables of joy, anxiety and anger (see Table 4). Self-efficacy was used as a control variable, which is displayed in model 1. Since previous studies have shown that students' engagement or lack of engagement predicts teacher emotions (Frenzel et al. 2011), these indicators were accounted for in model 2. Finally, model 3 also considered the interpersonal

Table 4 Results of hierarchical regression analyses predicting teacher emotions

\begin{tabular}{|c|c|c|c|c|c|c|c|c|c|}
\hline & \multicolumn{3}{|l|}{ Joy } & \multicolumn{3}{|l|}{ Anxiety } & \multicolumn{3}{|l|}{ Anger } \\
\hline & $b$ & $S E B$ & $\beta$ & $b$ & $S E B$ & $\beta$ & $b$ & $S E B$ & $\beta$ \\
\hline \multicolumn{10}{|l|}{ Model 1} \\
\hline Constant & 0.73 & 0.46 & & $3.15 * * *$ & 0.41 & & $3.39 * * *$ & 0.57 & \\
\hline SE_RB & 0.12 & 0.15 & 0.08 & -0.20 & 0.13 & -0.16 & -0.13 & 0.19 & -0.08 \\
\hline SE_ET & $0.56 * *$ & 0.17 & $0.33 * *$ & -0.05 & 0.16 & -0.03 & -0.12 & 0.21 & -0.06 \\
\hline SE_CM & 0.11 & 0.12 & 0.10 & $-0.29 * *$ & 0.11 & $-0.29 * *$ & -0.20 & 0.15 & -0.15 \\
\hline \multicolumn{10}{|l|}{ Model 2} \\
\hline Constant & $0.96^{*}$ & 0.40 & & $2.49 * * *$ & 0.43 & & $1.81 * * *$ & 0.46 & \\
\hline SE_RB & 0.15 & 0.10 & 0.10 & $-0.25 *$ & 0.11 & $-0.19 *$ & -0.24 & 0.12 & $-0.15^{*}$ \\
\hline SE_ET & $0.39 * *$ & 0.12 & $0.23 * *$ & 0.05 & 0.13 & 0.03 & 0.04 & 0.14 & 0.02 \\
\hline SE_CM & -0.12 & 0.08 & -0.11 & -0.10 & 0.09 & -0.10 & 0.15 & 0.10 & 0.11 \\
\hline ENG & $0.54 * * *$ & 0.07 & $0.49 * * *$ & $-0.26^{* * *}$ & 0.07 & $-0.28 * *$ & $-0.37 * * *$ & 0.08 & $-0.30 * * *$ \\
\hline L_DIS & $-0.28 * * *$ & 0.05 & $-0.33 * * *$ & $0.29 * * *$ & 0.06 & $0.39 * * *$ & $0.58 * * *$ & 0.06 & $0.62 * * *$ \\
\hline \multicolumn{10}{|l|}{ Model 3} \\
\hline Constant & $-0.81 *$ & 0.40 & & $3.53 * * *$ & 0.50 & & $2.69 * * *$ & & \\
\hline SE_RB & 0.01 & 0.09 & 0.01 & -0.17 & 0.11 & -0.13 & -0.17 & 0.12 & -0.10 \\
\hline SE_ET & $0.47 * * *$ & 0.10 & $0.27 * * *$ & 0.01 & 0.12 & -0.01 & 0.01 & 0.13 & 0.01 \\
\hline SE_CM & -0.11 & 0.07 & -0.09 & -0.11 & 0.09 & -0.11 & 0.14 & 0.09 & 0.11 \\
\hline ENG & $0.25 * * *$ & 0.07 & $0.23 * * *$ & -0.09 & 0.09 & -0.09 & $-0.22 *$ & 0.09 & $-0.18^{*}$ \\
\hline L_DIS & $-0.15^{* *}$ & 0.05 & $-0.18 * *$ & $0.21 * * *$ & 0.06 & $0.29 * * *$ & $0.52 * * *$ & 0.06 & $0.54 * * *$ \\
\hline CLOS & $0.70 * * *$ & 0.09 & $0.51 * * *$ & $-0.41 * * *$ & 0.12 & $-0.34 * * *$ & $-0.35 * *$ & 0.12 & $-0.22 * *$ \\
\hline$R^{2}$ model 1 & $0.20 * * *$ & & & $0.17 * * *$ & & & $0.06^{*}$ & & \\
\hline$R^{2}$ model 2 & $0.65 * * *$ & & & $0.47 * * *$ & & & $0.64 * * *$ & & \\
\hline$R^{2}$ model 3 & $0.77 * * *$ & & & $0.52 * * *$ & & & $0.66 * * *$ & & \\
\hline
\end{tabular}

$R^{2}$ change is highly significant $(p<0.001)$ for all comparisons, except between steps 2 and 3 for anger

$S E \_R B$ self-efficacy in relationship building, $S E_{-} E T$ self-efficacy in effective teaching of content, $S E \_C M$ selfefficacy in classroom management, ENG student engagement, $L \_D I S$ lack of discipline in class, CLOS closeness ${ }^{* * *} p<0.001 ;{ }^{* *} p<0.01 ;{ }^{*} p<0.05 ;{ }^{+} p<0.10$ 
aspects of TSR - namely closeness. Closeness was entered last in the model, as this indicator has mostly been neglected in research on teacher emotions to date. We wanted to investigate if closeness contributed above and beyond students' classroom engagement, to teacher emotions (= incremental validity).

As the results show, the explained variance significantly increased from model 1 to model 2 and further from model 2 to model 3. The strongest predictor of teachers' joy and anxiety was found to be closeness, whilst anger was best predicted by a lack of discipline in class. Lack of discipline in class also emerged as a significant negative predictor of teachers' joy and as a significant positive predictor for anxiety. Joy was further predicted by students' engagement in class, as was anger (negative association). Contrary to expectations, self-efficacy beliefs were not significantly related to anger and anxiety when simultaneously considering the relationship variables in the model, but self-efficacy beliefs in teaching content contributed to teachers' accounts of joy in class.

\section{Discussion}

The purpose of this study was to explore the predictors of teacher emotions in the classroom. Particular attention was given to the role of student behaviour and to the question of whether, and how, the interpersonal TSR - assessed as teachers" perception of "closeness" with their students - was related to teacher emotions during instruction. Teacher self-efficacy beliefs and their relationship with the students' classroom behaviour and the interpersonal TSR were also considered.

The results of the hierarchical regression analysis confirmed that the quality of the relationship between teachers and students was significantly related to teachers' emotional experiences during instruction. Closeness, reflecting the positive interpersonal relationship between students and teachers, was particularly important for teachers' experience of joy in the classroom, but was also a significant predictor of teachers' anger and anxiety. Teachers who felt connected with their students were more likely to report joy and less frequently anxiety and anger. In accordance with attachment theory (Cassidy and Shaver 2008), positive interpersonal relationships reflect security and, thus, do not only play an important role for students, but appear to function as antecedent of teachers' emotional wellbeing as well. This is also consistent with recent research on "teacher resilience" (Day and Gu 2014, p. 90), which revealed that pleasant, close and warm relationships with students form an integral part of the work context that contributes to teachers' successful coping in the teaching profession.

Furthermore and consistent with previous research (Chang 2013; Frenzel et al. 2011; Tsouloupas et al. 2010), students' engagement and discipline emerged as significant predictors of teacher joy, anxiety and anger. Teachers' anger, in particular, was associated with students' lack of discipline in class. As argued by Chang and Davis (2011), students' misbehaviour in the classroom represents a "threat to their [teachers] instructional or management goals" ( $p$. 102), which is strongly connected to negative emotions. Research by Liljestrom et al. (2007) and Sutton (2007) has demonstrated that teachers' anger is dominantly student directed and not self directed. In keeping with the findings of the present research, teachers' anger was evoked particularly if students' misbehaved or did not engage in learning. In the long term, frequently occurring negative feelings of teachers can lead to "compassion fatigue," a concept that was introduced by Chang and Davis (2011, p. 120) and which is conceptually linked with "depersonalization" (Durr et al. 2014; Hakanen et al. 2006). If teaching is experienced negatively in many situations, teachers run the risk of being alienated from students, which 
may decrease teaching quality, deteriorate the teacher-student relationship further and enhance the likelihood of developing burnout symptoms.

Interestingly, and contrary to our expectations, self-efficacy beliefs predicted teachers' joy, but were not found to be relevant negative predictors of teachers' anger and anxiety, after TSR variables were entered into the model. The general low impact of self-efficacy beliefs on teacher emotions might be partly caused by the fact that emotions were assessed on a class-specific level, whilst self-efficacy beliefs were measured on a class-unspecific level. Since teachers' selfefficacy beliefs may also be sensitive to specific classroom experiences, future research should further explore the issue of context sensitivity in self-efficacy beliefs by assessing them as classroom as well as subject-area specific, similarly to emotion research (Goetz et al. 2006).

The different predictive power of self-efficacy beliefs on teacher emotions might also be traced back to differences in the impact of classroom context on distinct teacher emotions. Joy might be triggered directly either by the activity of teaching ("teaching is fun") or by the teaching content ("biology is exciting"), as found in research on teacher enthusiasm (Kunter et al. 2011). In contrast, anger appears more dependent on the classroom context and teacherstudent interactions. This is consistent with the research of Frenzel and Goetz (2007) using diaries, which showed that the experience of anger varied more between classrooms than joy. Thus, anger might be a context-dependent emotion to a stronger degree (e.g. through different levels of student misbehaviour in different classrooms) than joy, which might be more bound to content and teacher characteristics, such as teaching enthusiasm or self-efficacy in teaching. These findings highlight the crucial role of the context in teacher emotion, a finding that parallels research on the domain specificity (Goetz et al. 2006) and situation specificity (Becker et al. 2014) of students' learning emotions. In the present study, this was addressed by investigating class-specific emotional experiences, rather than general emotions in teaching.

In terms of the conceptual model of teacher emotions developed by Frenzel (2014), the present study explored many of the proposed predictors. However, future studies should include the other predictor variables addressed in the model. First, the achievement level of students needs to be accounted for. Second, the dimension "socio-emotional behaviour of students" should also include a measure of students' socio-emotional behaviour directed to their classmates. This is because it is reasonable to assume that teacher emotions are not only affected by students' social behaviour directed towards them (e.g. by being disciplined, polite or showing disrespect towards the teacher), but also by the social behaviour displayed between students (e.g. being supportive of each other or excluding classmates).

In addition, our results showed that teachers' mean level of joy was relatively high, whilst in comparison, anger and in particular anxiety were notably lower. This is consistent with previous studies, which reported similar differences in positive and negative teacher emotions (Frenzel and Goetz 2007; Keller et al. 2014). Frenzel (2014), as well as Liljestrom et al. (2007), posited that anger might be underestimated given its incompatibility with prevalent teaching norms (e.g. caring for students). The same may be said about teachers' report of anxiety. Another possible explanation is the selectivity of the sample in the present study, which comprised a majority of experienced teachers. Ria et al. (2003) found that experienced teachers (= more than 5 years of teaching experience) were less emotionally challenged than beginning teachers, particularly with respect to anxiety.

Interestingly, our results also revealed that homeroom or form teachers experienced more joy, a better interpersonal relationship to students, as well as more student engagement in the classroom, compared to teachers who teach in minor subject areas. These findings could be explained by the fact that homeroom or form teachers typically spend extended time with their students, and this creates opportunities to get to know students better and develop positive 
teacher-student relationships. In turn, it connects to joy experiences as already shown in previous studies on primary school teachers (Hargreaves 2000).

The findings of the presented study should be interpreted with caution due to three methodological limitations. First, the use of self-report questionnaires to assess teacher emotions enhances the possibility of eliciting socially desirable responses. In relation to this, there seems to be some inconsistency in the literature in the finding that teachers report more positive than negative emotions but at the same time report burnout-which includes the dimension of "emotional exhaustion"- as a frequently occurring phenomenon in the teaching occupation (Urdan 2014, p. 240). This apparent contradiction might be traced to the two aforementioned potential explanations, or alternatively from a methodological perspective, to the use of self-report measures and/or to the second limitation in teacher emotion research to date, which is the participation of selected samples of volunteers. This was also the case in our study, which surveyed a sample of predominantly high motivated and experienced teachers, inherently expected to display lower levels of anxiety. This issue may point to a bias in the literature, as it is reasonable to expect that teachers who are struggling in the profession are unlikely to volunteer their participation in research that addresses a sensitive topic that is connected to one's self-worth. In order to get a more comprehensive understanding of the nature of teachers' emotional experiences, future research will need to come up with strategies for attracting teachers with diverse experiences. As this requires a trusting relationship between teachers and researchers in order for teachers to feel safe participating, a mixed-methods approach, incorporating small-scale studies and person-centred research, might be a fruitful addition to a quantitative assessment of teacher emotions (e.g. Scott and Sutton 2009).

A third limitation pertains to the cross-sectional design of the study, which prevents drawing any conclusions about causal relationship between the variables. As teacher emotions are dynamically linked to the context in which they emerge, reciprocal relations between TSR and emotions have to be assumed (Frenzel et al. 2011). The interplay of factors could only be assessed by using longitudinal and/or experimental approaches as well as by including situated data (e.g. observations) that allow for the study of teacher-student interactions in real time (e.g. Nolen et al. 2014; Turner and Fulmer 2013).

Future studies should address possible interaction effects between the variables, e.g. teachers with better interpersonal relationships with students, and with higher selfefficacy beliefs, might appraise students' lack of discipline as less threatening in comparison to their counterparts with poorer relationships with students, and lower selfefficacy (Chang and Davis 2011). Additionally, research needs to examine how a positive interpersonal TSR develops over time, and what teaching techniques or behaviours are conducive to this process. Humanistic approaches to education (Rogers et al. 2014) as well as research on emotional intelligence in the classroom (e.g. Mortiboys 2012) might provide fruitful theoretical grounding for exploring this research question (e.g. by assessing teachers' active listening skills or empathy; see, for example, the work on teacher engagement by Klassen et al. (2013)).

\section{Conclusion}

The results of this study indicate that student behaviour, the interpersonal TSR, and teacher emotions are strongly related. The ability to manage classrooms accordingly and to form positive interpersonal relationships with students can thus be regarded as important factors of teacher emotional wellbeing in the job. In turn, one can assume that teachers' positive 
emotions are likely to induce students' positive emotions as some recent studies have already shown (Becker et al. 2014; Frenzel et al. 2009) and referred to as "emotional contagion" (Fischer 2007). Therefore, positive teacher emotions may not only be essential for the wellbeing of teachers but they may also affect students' wellbeing and, in turn, learning in class.

These results lead to the conclusion that teachers' ability to connect well with students can be regarded as an important skill to target in professional development. Whilst strategies that affect the professional aspects of the TSR (e.g. classroom management; motivating students which affects student engagement) are already explicitly addressed in teacher competence models, such as the one introduced by the COACTIV study of Baumert and Kunter (2013), instructional strategies that aim at fostering the interpersonal TSR have been largely overlooked in teacher education curricula. As Jennings and Greenberg (2009, p. 495) have observed, "the current educational system appears to assume that teachers have the requisite SEC [socio-emotional competence] to create a warm and nurturing learning environment, be emotionally responsive to students, form supportive and collaborative relationships with difficult and demanding parents [...]." In fact, (socio)-emotional competence can be regarded as a competence cluster that requires training just like other teacher competencies. There is emerging evidence that TSR issues tend to evoke tensions and dilemmas accompanied by various emotions, particularly in beginning teachers, which reflects insecurity in regard to relationship issues (Pillen et al. 2013).

Thus, reflecting on social interaction in the classroom and its accompanied emotions should be an important component of teacher pre- and in-service education programmes, with a view to develop and enhance teachers' (socio)-emotional competence (Garner 2010; Jennings and Greenberg 2009).

Acknowledgments This research was funded by the Austrian Science Fund (FWF): J 3164-G17.

\section{References}

Abel, M. H., \& Sewell, J. (1999). Stress and burnout in rural and urban secondary school teachers. The Journal of Educational Research, 92, 287-293. doi:10.1080/00220679909597608.

Ang, R. P. (2005). Development and validation of the teacher-student relationship inventory using exploratory and confirmatory factor analysis. The Journal of Experimental Education, 74, 55-73. doi:10.3200/JEXE. 74.1.55-74.

Baumeister, R. F., \& Leary, M. R. (1995). The need to belong: desire for interpersonal attachments as a fundamental human motivation. Psychological Bulletin, 117, 497-529. doi:10.1037/0033-2909.117.3.497.

Baumert, J., \& Kunter, M. (2013). The COACTIV model of teachers' professional competence. In M. Kunter, J. Baumert, W. Blum, U. Klusmann, S. Krauss, \& M. Neubrand (Eds.), Cognitive activation in the mathematics classroom and professional competence of teachers. Results from the COACTIV project (pp. 25-48). New York: Springer.

Baumert, J., Blum, W., Brunner, M., Dubberke, T., Jordan, A., Klusmann, U., Krauss, S., Kunter, M., Löwen, K., Neubrand, M., \& Yi-Miau, T. (2008). Professionswissen von Lehrkräften, kognitiv aktivierender Mathematikunterricht und die Entwicklung von mathematischer Kompetenz (COACTIV): Dokumentation der Erhebungsinstrumente. Berlin: Max-Planck Institut für Bildungsforschung.

Becker, E. S., Goetz, T., Morger, V., \& Ranellucci, J. (2014). The importance of teachers' emotions and instructional behavior for their students' emotions - an experience sampling analysis. Teaching and Teacher Education, 43, 15-26. doi:10.1016/j.tate.2014.05.002.

Bergin, C., \& Bergin, D. (2009). Attachment in the classroom. Educational Psychological Review, 21, 141-170. doi:10.1007/s10648-009-9104-0. 
Brackett, M. A., Floman, J. L., Ashton-James, C., Cherkasskiy, L., \& Salovey, P. (2013). The influence of teacher emotion on grading practices: a preliminary look at the evaluation of student writing. Teachers and Teaching: Theory and Practice, 19, 634-646. doi:10.1080/13540602.2013.827453.

Butler, R. (2012). Striving to connect: extending an achievement goal approach to teacher motivation to include relational goals for teaching. Journal of Educational Psychology, 104, 726-742. doi:10.1037/a0028613.

Cassidy, J., \& Shaver, P. R. (Eds.). (2008). Handbook of attachment: theory, research, and clinical applications. New York: Guilford.

Chang, M.-L. (2013). Toward a theoretical model to understand teacher emotions and teacher burnout in the context of student misbehavior: appraisal, regulation and coping. Motivation and Emotion, 37, 799-817. doi: 10.1007/s11031-012-9335-0.

Chang, M.-L., \& Davis, H. A. (2011). Understanding the role of teacher appraisals in shaping the dynamics of their relationships with students: deconstructing teachers' judgments of disruptive behavior/students. In P. A. Schutz \& M. Zembylas (Eds.), Advances in teacher emotion research (pp. 95-127). Heidelberg: Springer.

Cornelius-White, J. (2007). Learner-centered teacher-student relationships are effective: a meta-analysis. Review of Educational Research, 77, 113-143. doi:10.3102/003465430298563.

Day, C., \& Gu, Q. (2011). Teacher emotions: well being and effectiveness. In P. A. Schutz \& M. Zembylas (Eds.), Advances in teacher emotion research (pp. 15-31). Heidelberg: Springer.

Day, C., \& Gu, Q. (2014). Resilient teachers, resilient schools. Building and sustaining quality in testing times. London: Routledge.

Deci, E. L., \& Ryan, R. M. (Eds.). (2002). Handbook of self-determination research. Rochester: University of Rochester Press.

Demetriou, H., Wilson, E., \& Winterbottom, M. (2009). The role of emotion in teaching: are there differences between male and female newly qualified teachers' approaches to teaching? Educational Studies, 35(4), 449-473. doi:10.1080/03055690902876552.

Den Brok, P., van der Want, A., Beijaard, D., \& Wubbels, T. (2013). The interpersonal dimension in the classroom: a model of teachers' interpersonal role identity, appraisal and teacher-student relationships. In M. Newberry, A. Gallant, \& P. Riley (Eds.), Emotion and school: understanding how the hidden curriculum influences relationships, leadership, teaching, and learning (pp. 141-159). UK: Emerald.

Durr, T., Chang, M.-L., \& Carson, R. L. (2014). Curbing teacher burnout: the transactional factors of teacher efficacy and emotion management. In P. W. Richardson, S. A. Karabenick, \& H. M. G. Watt (Eds.), Teacher motivation. Theory and practice (pp. 198-213). New York: Routledge.

Ellsworth, P. C., \& Scherer, K. R. (2003). Appraisal processes in emotion. In R. J. Davidson, K. R. Scherer, \& H. Hill Goldsmith (Eds.), Handbook of affective sciences (pp. 572-595). Oxford: University Press.

Fischer, A. H. (2007). Emotional contagion. In R. F. Baumeister \& K. D. Vohs (Eds.), Encyclopedia of social psychology (pp. 291-293). Thousand Oaks: Sage.

Frenzel, A. C. (2014). Teacher emotions. In R. Pekrun \& L. Linnenbrink-Garcia (Eds.), International handbook of emotions in education (pp. 494-519). New York: Routledge.

Frenzel, A. C., \& Goetz, T. (2007). Emotionales Erleben von Lehrkräften beim Unterrichten [Teacher emotions during instruction]. Zeitschrift für Pädagogische Psychologie, 21(3/4), 283-295. doi:10.1024/1010-0652.21. 3.283 .

Frenzel, A. C., Goetz, T., Lüdtke, O., Pekrun, R., \& Sutton, R. (2009). Emotional transmission in the classroom: exploring the relationship between teacher and student enjoyment. Journal of Educational Psychology, 101, 705-716. doi:10.1037/a0014695.

Frenzel, A. C., Pekrun, R., \& Goetz, T. (2010). Achievement Emotions Questionnaire for Teachers (AEQteacher)—user's manual. University of Munich: Department of Psychology.

Frenzel, A. C., Goetz, T., Stephens, E. J., \& Jacob, B. (2011). Antecedents and effects of teachers' emotional experiences: an integrated perspective and empirical test. In P. A. Schutz \& M. Zembylas (Eds.), Advances in teacher emotion research (pp. 129-151). Heidelberg: Springer.

Galant, A. (2013). Self-conscious emotion: how two teachers explore the emotional work of teaching. In M. Newberry, A. Gallant, \& P. Riley (Eds.), Emotion and school: understanding how the hidden curriculum influences relationships, leadership, teaching, and learning (pp. 163-181). UK: Emerald.

Garner, P. W. (2010). Emotional competence and its influences on teaching and learning. Educational Psychology Review, 22, 297-321. doi:10.1007/s10648-010-9129-4.

Glaeser-Zikuda, M., Stuchlikova, I., \& Janik, T. (2013). Emotional aspects of learning and teaching: reviewing the field- discussing the issues. Orbis Scholae, 7(2), 7-22.

Goetz, T., Frenzel, A. C., Pekrun, R., \& Hall, N. C. (2006). The domain specificity of academic emotional experiences. Journal of Experimental Education, 75, 5-29. doi:10.3200/JEXE. 75.1.5-2.

Hagenauer, G., \& Volet, S. E. (2014). Teacher-student relationship at university: an important yet underresearched field. Oxford Review of Education, 40(3), 370-388. doi:10.1080/03054985.2014.921613. 
Hakanen, J., Bakker, A. B., \& Schaufeli, W. B. (2006). Burnout and work engagement among teachers. Journal of School Psychology, 43, 495-513. doi:10.1016/j.jsp.2005.11.001.

Hargreaves, A. (1998). The emotional practice of teaching. Teaching and Teacher Education, 14, 835-854.

Hargreaves, A. (2000). Mixed emotions: teachers' perceptions of their interactions with students. Teaching and Teacher Education, 16(8), 811-826. doi:10.1016/S0742-051X(00)00028-7.

Hascher, T. (2010). Learning and emotion: perspectives for theory and research. European Research Journal, 9 , 13-28. doi:10.2304/eerj.2010.9.1.13.

Järvelä, S. (Ed.). (2011). Social and emotional aspects of learning. Amsterdam: Elsevier.

Jennings, P. A., \& Greenberg, M. T. (2009). The prosocial classroom: teacher social and emotional competence in relation to student and classroom outcomes. Review of Educational Research, 79, 491-525. doi:10.3102/ 0034654308325693.

Jerusalem, M., Drössler, S., Kleiner, D., Klein-Heßling, J., Mittag, W., \& Röder, B. (2009). Förderung von Selbstwirksamkeit und Selbstbestimmung im Unterricht. Skalen zur Erfassung von Lehrer- und Schülermerkmalen[Fostering self-efficacy and self-determination in instruction: Scales for measuring teacher and student characteristics]. Retrieved on 17.07 .2014 from https://www. erziehungswissenschaften.hu-berlin.de/paedpsych/forschung/Skalenbuch_FoSS.pdf.

Juvonen, J. (2006). Sense of belonging, social bonds, and school functioning. In P. A. Alexander \& P. H. Winne (Eds.), Handbook of educational psychology (2nd ed., pp. 655-673). Mahwah: Lawrence Erlbaum.

Keller, M., Frenzel, A. E., Goetz, T., Pekrun, R., \& Hensley, L. (2014). Exploring teacher emotions. A literature review and an experience sampling study. In P. W. Richardson, S. A. Karabenick, \& H. M. G. Watt (Eds.), Teacher motivation. Theory and practice (pp. 69-82). New York: Routledge.

Klassen, R. M., Bong, M., Usher, E. L., Chong, W. H., Huan, V. S., Wong, I. Y. F., \& Georgiou, T. (2009). Exploring the validity of a teachers' self-efficacy scale in five countries. Contemporary Educational Research, 34, 67-76.

Klassen, R. M., \& Chiu, M. M. (2010). Effects on teachers' self-efficacy and job satisfaction: teacher gender, years of experience, and job stress. Journal of Educational Psychology, 102, 741-756. doi:10.1037/a0019237.

Klassen, R. M., Perry, N. E., \& Frenzel, A. C. (2012). Teachers' relatedness with students: an underemphasized component of teachers' basic psychological needs. Journal of Educational Psychology, 104, 50-65. doi:10. $1037 / \mathrm{a} 0026253$.

Klassen, R. M., Yerdelen, S., \& Durksen, T. L. (2013). Measuring teacher engagement: development of the engaged teachers scale (ETS). Frontline Learning Research, 2, 33-52.

Kunter, M., Frenzel, A., Nagy, G., Baumert, J., \& Pekrun, R. (2011). Teacher enthusiasm: dimensionality and context specificity. Contemporary Educational Psychology, 36, 289-301. doi:10.1016/j.cedpsych.2011.07.001.

Lazarus, R. S. (1999). Stress and emotion. A new synthesis. London: Free Association Books.

Liljestrom, A., Roulston, K., \& Demarrais, K. (2007). "There is no place for feeling like this in the workplace": women teachers' anger in school settings. In P. A. Schutz \& R. Pekrun (Eds.), Emotion in education (pp. 275-291). Amsterdam: Elsevier.

Lynch, M., \& Cicchetti, D. (1997). Children's relationships with adults and peers: an examination of elementary and junior high school students. Journal of School Psychology, 35, 81-99. doi:10.1016/S0022-4405(96)00031-3.

Mansfield, C., \& Beltman, S. (2014). Teacher motivation from a goal content perspective: beginning teachers goals for teaching. International Journal of Education Research, 65, 54-64. doi:10.1016/j.ijer.2013.09.010.

McCarthy, C. J., Lineback, S., \& Reiser, J. (2015). Teacher stress, emotion, and classroom management. In E. T. Emmer \& E. J. Sabornie (Eds.), Handbook of classroom management (2nd ed., pp. 301-321). New York: Routledge.

Mortiboys, A. (2012). Teaching with emotional intelligence (2nd ed.). Oxon: Routledge.

Muthén, L.K., \& Muthén, B.O. (1998-2012). Mplus user's guide. Seventh Edition. Los Angeles: Muthén \& Muthén.

Newberry, M., \& Davis, H. A. (2008). The role of elementary teachers' conceptions of closeness to students on their differential behavior in the classroom. Teaching and Teacher Education, 24, 1965-1985. doi:10.1016/j. tate.2008.02.015.

Newberry, M., Gallant, A., \& Riley, P. (Eds.). (2013). Emotion and school: understanding how the hidden curriculum influences relationships, leadership, teaching, and learning. UK: Emerald.

Nolen, S. B., Ward, C. J., \& Horn, I. S. (2014). Changing practices. A situative account of teachers' motivations to learn. In P. W. Richardson, S. A. Karabenick, \& H. M. G. Watt (Eds.), Teacher motivation. Theory and practice (pp. 167-181). New York: Routledge.

O'Connor, K. E. (2006). "You choose to care": teachers, emotions and professional identity. Teaching and Teacher Education, 24, 117-126. doi:10.1016/j.tate.2006.11.008.

Oplatka, I. (2007). Managing emotions in teaching: toward an understanding of emotions displays and caring as nonprescribed role elements. Teachers College Record, 109, 1374-1400.

Pekrun, R. (2006). The control-value theory of achievement emotions: assumptions, corollaries, and implications for educational research and practice. Educational Psychology Review, 18, 315-341. doi:10.1007/s10648-006-9029-9. 
Pekrun, R., \& Linnenbrink-Garcia, L. (Eds.). (2014). International handbook of emotions in education. New York: Routledge.

Pianta, R. C. (2001). Teacher-student relationship scale. Lutz: Psychological Assessment.

Pillen, M. T., Beijaard, D., \& den Brok, P. J. (2013). Tensions in beginning teachers' professional development, accompanying feelings and coping strategies. European Journal of Teacher Education, 36, 240-260. doi:10. 1080/02619768.2012.696192.

Postareff, L., \& Lindblom-Ylänne, S. (2011). Emotions and confidence within teaching in higher education. Studies in Higher Education, 36, 799-813. doi:10.1080/03075079.2010.483279.

Ria, L., Sève, C., Saury, J., Theureau, J., \& Durand, M. (2003). Beginning teachers' situated emotions: a study of first classroom experiences. Journal of Education for Teaching, 29, 219-233. doi:10.1080/ 0260747032000120114 .

Riley, P. (2009). An adult attachment perspective on the student-teacher relationship \& classroom management difficulties. Teaching and Teacher Education, 25, 626-635. doi:10.1016/j.tate.2008.11.018.

Riley, P. (2011). Attachment theory and the teacher-student relationship. London: Routledge.

Rogers, C. R., Lyon, H. C., \& Tausch, R. (2014). On becoming an effective teacher. Person-centered teaching, psychology, philosophy, and dialogues with Carl R. Rogers and Harold Lyon. Oxford: Routledge.

Roorda, D. L., Koomen, H. M. Y., Spilt, J. L., \& Oort, F. J. (2011). The influence of affective teacher-student relationships on students' school engagement and achievement: a meta-analytic approach. Review of Educational Research, 81, 493-529. doi:10.3102/0034654311421793.

Scherer, K. R. (2004). Feelings integrate the central representation of appraisal-driven response organization in emotion. In A. S. R. Manstead, N. Frijda, \& A. Fischer (Eds.), Feelings and emotions (pp. 136-157). Cambridge: Cambridge University Press.

Schutz, P. A. (2014). Inquiry on teachers' emotion. Educational Psychologist, 49, 1-12. doi:10.1080/00461520. 2013.864955.

Schutz, P. A., \& Pekrun, R. (2007). Emotion in education. Amsterdam: Elsevier.

Schutz, P. A., \& Zembylas, M. (Eds.). (2011). Advances in teacher emotion research. The impact of teachers' lives. Heidelberg: Springer.

Schutz, P. A., Aultman, L. P., \& Williams-Johnson, M. R. (2011). Educational psychology perspectives on teachers' emotions. In P. A. Schutz \& M. Zembylas (Eds.), Advances in teacher emotion research (pp. 195212). Heidelberg: Springer.

Scott, C., \& Sutton, R. E. (2009). Emotions and change during professional development for teachers. Journal of Mixed Methods Research, 3, 151-171. doi:10.1177/1558689808325770.

Skaalvik, E. M., \& Skaalvik, S. (2007). Dimension of teacher self-efficacy and relation with strain factors, perceived collective teacher efficacy, and teacher burnout. Journal of Educational Psychology, 99, 611-625. doi:10.1037/0022-0663.99.3.611.

Skaalvik, E. M., \& Skaalvik, S. (2010). Teacher self-efficacy and teacher burnout: a study of relations. Teaching and Teacher Education, 26, 1059-1069. doi:10.1016/j.tate.2009.11.001.

Skinner, E. A., \& Belmont, M. J. (1993). Motivation in the classroom: reciprocal effects of teacher behavior and student engagement across the school year. Journal of Educational Psychology, 85, 571-581. doi:10.1037/ 0022-0663.85.4.571.

Spilt, J. L., Koomen, H. M., \& Thijs, J. T. (2011). Teacher wellbeing: the importance of teacher-student relationships. Educational Psychological Review, 23, 457-477. doi:10.1007/s10648-011-9170-y.

Sutton, R. E. (2007). Teachers' anger, frustration, and self-regulation. In P. A. Schutz \& R. Pekrun (Eds.), Emotion in education (pp. 259-274). Amsterdam: Elsevier.

Sutton, R. E., \& Wheatley, K. F. (2003). Teachers' emotions and teaching: a review of the literature and directions for future research. Educational Psychology Review, 15, 327-358. doi:10.1023/ A:1026131715856.

Tal, Z., \& Babad, E. (1990). The teacher's pet phenomenon: rate of occurrence, correlates, and psychological costs. Journal of Educational Psychology, 82, 637-645. doi:10.1037/0022-0663. 82.4.637.

Trigwell, K. (2012). Relations between teachers' emotions in teaching and their approaches to teaching in higher education. Instructional Science, 40, 607-621. doi:10.1007/s1125-011-9192-3.

Tschannen-Moran, M., \& Woolfolk Hoy, A. (2001). Teacher efficacy: capturing an elusive construct. Teaching and Teacher Education, 17, 783-805. doi:10.1016/S0742-051X(01)00036-1.

Tsouloupas, C. N., Carson, R. L., Matthews, R., Grawitch, M. J., \& Barber, L. K. (2010). Exploring the association between teachers' perceived student misbehavior and emotional exhaustion: the importance of teacher efficacy beliefs and emotion regulation. Educational Psychology, 30(2), 173-189. doi:10.1080/ 01443410903494460 . 
Turner, J. C., \& Fulmer, S. A. (2013). Observing interpersonal regulation of engagement during instruction in middle school classrooms. In S. Volet \& M. Vauras (Eds.), Interpersonal regulation of learning and motivation. Methodological advances (pp. 147-170). London: Routledge.

Urdan, T. (2014). Concluding commentary: understanding teacher motivation. What is known and what more is to learn. In P. W. Richardson, S. A. Karabenick, \& H. M. G. Watt (Eds.), Teacher motivation. Theory and practice (pp. 227-246). New York: Routledge.

Vieluf, S., Kunter, M., \& van de Vijver, F. J. R. (2013). Teacher self-efficacy in cross-national perspective. Teaching and Teacher Education, 35, 92-103. doi:10.1016/j.tate.2013.05.006.

Wellborn, J. G., \& Connell, J. P. (n.d.). Student's achievement-relevant actions in the classroom (SARAC). A teacher report and a self-report measure of student engagement vs. disaffection in school. Retrieved on 17.7.2014 from https://www.pdx.edu.

Williams-Johnson, M., Cross, D., Hong, J., Aultmann, L., Osbon, J., \& Schutz, P. (2008). “There are no emotions in math": how teachers approach emotions in the classroom. Teachers College Record, 110, 1574-1610.

Woolfolk, A. E., \& Hoy, W. K. (1990). Prospective teachers' sense of efficacy and beliefs about control. Journal of Educational Psychology, 82, 81-91. doi:10.1037/0022-0663.82.1.81.

Zembylas, M. (2002). Constructing genealogies of teachers' emotions in science teaching. Journal of Research in Science Teaching, 39, 79-103. doi:10.1002/tea.10010.

Gerda Hagenauer, Institute of Educational Science, Department of Research on School, Learning and Instruction, University of Bern, Fabrikstrasse 8, CH-3012 Bern, Switzerland; Email: gerda.hagenauer@edu.unibe.ch

Current themes of research:

Emotions and motivation in learning and teaching at school and in higher education; teacher-student relationship; mixed methods in educational research

Most relevant publications in the field of Psychology of Education:

Hagenauer, G., \& Volet, S. E. (2014). Student-teacher relationship at university: an important yet underresearched field. Oxford Review of Education, 40 (3), 370-388.

Hagenauer, G., \& Volet, S. E. (2014). "I don’t think I could, you know, just teach without any emotion": Exploring the nature and origin of university teachers' emotions. Research Papers in Education, 29 (2), 240-262.

Hagenauer, G., Reitbauer, E., \& Hascher, T. (2013). "It's cool but challenging." The relevance of basic needfulfillment for students' school enjoyment and emotional experiences at the transition from primary to secondary education, Orbis Scholae, 7 (2), 23-42.

Hagenauer, G., \& Hascher, T. (2010). Learning enjoyment in early adolescence. Educational Research and Evaluation, 16 (6), 495-516.

Tina Hascher, Institute of Educational Science, Department of Research on School, Learning and Instruction, University of Bern, Fabrikstrasse 8, CH-3012 Bern, Switzerland; Email: tina.hascher@edu.unibe.ch

Current themes of research:

Emotional and motivational aspects of learning and teaching; wellbeing in school; teacher education

Most relevant publications in the field of Psychology of Education:

Hagenauer, G. \& Hascher, T. (2014). Early adolescents' enjoyment experienced in learning situations at school and its relation to student achievement. Journal of Education and Training Studies, 2(2), 20-30.

Hascher, T. (2012). Well-being and learning in school. In N. M. Seel (Ed.), Encyclopedia of the Sciences of Learning. Heidelberg: Springer.

Hascher, T. (2011). Wellbeing. In S. Järvelä (Ed.), Social and emotional aspects of learning (pp. 99-106). Oxford: Elsevier.

Hascher, T. (2010). Learning and emotion-perspectives for theory and research. European Educational Research Journal, 9(1), 13-28. 
Hascher, T., \& Hagenauer, G. (2010). Alienation from school. International Journal of Educational Research, 49, 220-232.

Simone Volet, School of Education, Murdoch University, South Street 90, Murdoch, Perth, Australia. E-mail: s.volet@murdoch.edu.au.

Current themes of research:

Self and social regulation of learning. Cognitive, motivational and emotional aspects of learning and teaching. Collaborative learning processes. Cultural issues in higher education.

Most relevant publications in the field of Psychology of Education:

Khosa, D. \& Volet, S. E. (2014). Cognitive activity and metacognitive regulation during collaborative learning: Can it explain differences in conceptual understanding? Metacognition and Learning, 9 (3), 287-307.

Hagenauer, G., \& Volet, S.E. (2014). Student-teacher relationship at university: An important yet underresearched field. Oxford Review of Education, 40 (3), 370-388.

Volet, S.E. Vauras, M., Khosa, D., \& Iisakala, T. (2013). Metacognitive regulation in collaborative learning: Theoretical advances and methodological contextualizations. In S. Volet \& M. Vauras (Eds). Interpersonal regulation of learning and motivation: Methodological advances (pp. 67-101). London: Routledge.

Volet, S.E., Summers, M., \& Thurman, J. (2009) High-level co-regulation in collaborative learning: How does it emerge and how is it sustained? Learning and Instruction, 19, 128-143.

Volet, S.E., Vauras, M., \& Salonen, P. (2009). Self- and social regulation in learning contexts: An integrative perspective. Educational Psychologist, 44 (4), 215-226. 